\title{
ART. XXIX VAN DIE NEDERLANDSE GELOOFSBELYDENIS
}

\author{
Dr. C. van der Waal (Pretoria)
}

\section{Die Teks van art. 29 NGB}

\section{Die aanduiding van die ware kerk}

Daar word allereers gespreek oor die noodsaak om ,diligemment' en ,avec bonne prudence par la parole de Dieu' te onderskei wat die ware kerk is. Die eerste Nederlandse teks gee die belydenis aldus: „Wy ghelooven, dat men moet neerstelicken onderscheiden met goeder wijsheyt by den woorde Gods, welcke de rechte ende ware kerk sy".

Hieruit blyk dit dat die huidige Afrikaanse teks nie heeltemal korrek „ywer en versigtigheid uit die Woord van God" naas mekaar stel nie.

„Met ywer" is 'n bywoord (,ywerig') wat die onderskeiding nader bepaal. Ons moet ywerig, (diligent) onderskei. Die ,en' wat volg is 'n verklarend, eksplikatief wat in die eerste uitgawe van 1561 ontbreek. Dit verklaar die manier waarop dit gedoen moet word, nie ru en rof nie, maar ,met goeder wijsheyt' of "met goede voorsigtigheyt". (Circumspecte in die Latynse teks), met omsigtigheid. Daarom hang hierdie onderskeiding nie af van menslike oorwegings nie. Soos die vorige artikel reeds duidelik gemaak het, kan onderskeiding op 'n wyse manier slegs uit die Woord van God gebeur. Die prudentia, die wysheid, die versigtigheid, die ,bonne prudence' is dus onlosmaaklik gekoppel aan die Woord van God.

Die eerste uitgawe wys verder aan wat die ,rechte en ware Kerke zy". Die toevoeging "rechte" wys reeds duidelik heen na die ,ware'. "Rechte" beteken ook wettige, legitieme. Dit gaan hier om die kerk soos wat dit volgens die Woord ingerig is.

Die volgende sinsdeel verklaar die noodsaaklikheid om die regte, ware kerk te onderskei. Huidige sektes eien hulle ook die naam „kerk” toe (bv. die Wederdopers, en Roomse gemeentes). Gedurende die Reformasie is na Rome as ,,sekte" verwys.

Revius spreek in sy Griekse vertaling aanvanklik nie van die kerk nie, maar van die ondersoek na "wat die genoemde heilige kerk is". Hy verwys hier dus na art. 27. Dit gaan in art. 29 en 27 nie om twee verskillende kerke nie, asof art. 27 oor die onsigbare en art. 29 oor die sigbare kerk sou handel nie. Nee, sê Revius, dit gaan in art. 29 om die sigbare kerk waarvan reeds in art. 27 sprake was.

Nadat die donatistiese misvatting afgewys is, wat die "ware kerk" in 'n ecclesiola in ecclesia van uitverkorenes soek, word nader ingegaan op die kenmerke van die ware, „rechte”, legitieme kerk.

\section{Die notae verae ecclesiae}

Die eerste:

Die gebruik van die „louter leere des Euangeliums”(1561); 
,So de Kercke de reyne Predicatie des Evangelii oeffendt' (1566). Franse teks van 1561: „Si l'Eglise use la pure predication de l'Euangile”. Afrikaanse teks: ,As die Kerk die suiwere prediking van die Evangelie uitoefen'. „Louter”,/,puur” word „rein” en in die Afrikaanse ,suiwer". Die woord ,suiwer' is vir misverstand vatbaar omdat daar nou eenmaal die onderskeiding tussen ,suiwer' en ,minder suiwer' is. Daar moet 'n woord gekies word wat dit uitsluit. Dit moet duidelik wees dat hier geen gradasies toegelaat word nie. In „louter" sit iets van sola Scriptura: net die Skrif alleen.

Die tweede:

die rein bediening van die sakramente soos Christus verorden het: „La pure administration des Sacraments comme Christ les a ordonnez". Die Latynse teks praat van pura administratio van die prediking van die evangelie sincera administratio van die sakramente ex Christi praecepto. Ek vra aandag vir hierdie onderskeid. Ons Afrikaanse teks vertaal weer ,rein" met „,suiwer". Die Latynse teks laat egter aanvoel, dat dit hier nie soseer gaan om suiwer in die sin van ortodoks, regsinnig nie (,zuiwer op de graad'), maar bedoel sonder bymengsels, sonder verkeerde toevoegsels, opreg, ongesofistikeerd, een-voudig Daar sal 'n woord gekies moet word wat dit sincera administratio beter aandui.

Daar kan verder ook aandag gegee word aan die woord „gebruik" van die sakramente. Die kopie van 1561 en 1566 spreek van bediening van die sakramente, ,la pure administration des Sacraments', die onbesoedelde administrasie van die sakramente. Dit gaan hier nie om 'n regte gebruik deur die ontvangers van die sakramente nie, maar 'n regte beheer en bediening van die sakramente.

Die derde:

gebruik van de „Christelijcke straffe" (1561) of ,kerkelicke Discipline" (1566), om ,de ghebreken te beteren" (1561) of om „de sonden te straffen” (1566), „Pour corriger les vices”. Die oorspronklike bedoeling (,corriger') kom beter uit deur die „te beteren" van 1561 as deur die later tekste wat net van „om te straf" spreek. Die bedoeling van die tug is positief, korrigerend.

Die Samevatting: „Corts, so men hem na het reyne woordt Gods reguleert,

met verwerpen alle des ghenes, dat daer tegen is, ende houden Jesum Christum voor het eenich Hooft, daer door mach men versekert syn, de ware Kercke te bekennen".

Die uitgawes van 1611 en 1619 voeg hieraan nog toe dat dit vir niemand geoorloof is om hom daarvan af te skei nie.

Dit is opmerklik dat die Latyn ,as almal hulle gedra ooreenkomstig die suiwere Woord van God" weergee met si ad normam Verbi divini omnia exigantur. Hieruit blyk dat ons Afrikaanse ver- 
taling aanvegbaar is. Dit gaan nie om die gedrag van die kerklede in die eerste plek nie. Daaroor word later gespreek. Dit gaan om die reëls, die norme wat in praktyk gebring word by die administrasie van die kerk, die beheer oor die bont genadegawes van God. Daar is nogal 'n afstand tussen die: ,Somen hem na het reyne woordt Gods reguleert' en die: as almal hulle ooreenkomstig die suiwere Woord van God gedra". Hierdie laaste kan die gedagte aan fatsoenlike en oppassende christene wek. Die eis is hier egter: die regte norme, reëls moet in ag geneem word: Dit vra meer as 'n humanisties-etiese benadering. Die kerkorde kom in die prentjie. Dit blyk wel uit die verwysing na Christus as die enigste Hoof en uit die eis van verwerping van alles wat teen die „pure parole de Dieu" ingaan.

Art. 32 eis weer om alles te verwerp wat reëlreg ingaan teen die Woord van God. Hier word gewag gemaak van 'n verwerping van alle dinge wat ingaan teen die sola Scriptura. „Si on se regle selon la pure parole de Dieu". Die eis is nogal omvattend. Dit dring steeds op nadere reformasie aan. Die weg vir die appèl op die Bybel word hier oopgehou vgl. art. 7 NGB). By hierdie gehoorsaamheid staan of val die ware kerk.

\section{Die kenmerke van die ware christene}

Die Belydenis rig hom steeds teen die novatianisme. Die Wederdopers het die ideaal van 'n kerk van heiliges geken. In hierdie paragraaf word daarmee rekening gehou dat ook hulle wat „van" die kerk is nogtans moet stry teen hul sondes. Die verwyt van die Roomse kerk dat die Reformasie net formele aansluiting soek en 'n maklike vergewing sonder stryd om heiligmaking predik, word hier weerlê. Die NGB stry altyd op twee fronte.

Die teks is hier verder duidelik

\section{Die notae van die valse kerk}

So veel as daar oor die onsigbaarheid van die ware kerk gespreek is, so min is daar oor die onsigbaarheid van die valse kerk gediskusseer. Dit manifesteer hom sigbaar.

Die woord „valse kerk" kom in alle vertalings voor. Die Griekse van Revius het hier die insiggewende woord pseudonumos ekklesia. Ons moet ons nie laat mislei deur die betekenis van ons woord ,pseudoniem' wat skuilnaam beteken nie. Ons moet vashou aan die bedoeling van die na-klassieke term pseudonumos: om 'n valse naam te dra. Met "vals" is dus nie 'n psigologiese eienskap bedoel soos in „valse man" nie. Hier is sprake van 'n regsterm, soos in ,valse identiteitsbewys". Ons herinner aan die tipering van die ware kerk in die eerste uitgawe van die NGB: „rechte ende ware Kerk”. Met valse kerk is die illegitieme kerk bedoel, die kerk wat voorgee om kerk te wees maar dit nie is nie. Ons kan hier verwys na die begin van die artikel: hulle wat hulle met die naam Kerk dek.

Interessant is dit om in hierdie verband te let op Openb. 2:9 wat die oorspronklike belydenis aanhaal: Christus spreek met Efese oor hulle wat sê dat hulle Jode is, maar hulle is dit nie. Teen die 
einde van hierdie artikel word hierdie teks weer aangehaal waar gespreek word oor hulle wat diegene wat lewe volgens die Woord van God vervolg.

Die verwysing na die sinagoge van satan het verband met die boupraktyke van die Roomse kerk. In baie katedrale was weerskante van die ingang die beelde van ecclesia en synagoga aangebring. Ikonigrafies gaan dit terug op die konfrontasie in die eerste eeue tussen die kerk en sinagoge. Wiclif is deur die konsilie van Konstans 14141418) onder andere veroordeel omdat hy beweer het dat die kerk van Rome die sinagoge van die satan was (Denzinger, no. 617). Met sterk taal soos ons van hom kan verwag, het John Knox Wiclif gevolg in sy Skotse Belydenis van 1560; , that Sathan from the beginning hes labourit to decke his pestilente Synagogue with the tytle of the kirk of GOD" (Cap. 16). "It is ane thing maist requisit, that the trew Kirk be decernit frome thee fylthie Synagoge be clear and perfect notes, leste we, being desaved, reseave and embrace, to our awin condemnation, the one for the utter" (idem).

Uit die formulering blyk wel hoe die NGB hom op dieselfde manier as die Skotse uitdruk. Altwee gaan saaklik terug op die Franse konfessie (1559).

Die Reformasie durf teen Rome sê dat dit 'n sinagoge van satan was. Die roem van die beelde langs die ingangspoorte van die gotiese katedrale was 'n leuen, Pseudonumos ekklèsia.

\section{Die kenmerke van die valse kerk loop parallel met die van die ware kerk}

1. Dit skryf aan haarself en haar ordinansie meer mag en outoriteit toe as aan die Woord van God. Die oorspronklike Franse teks het net: ,authorité'. Die Afrikaanse teks spreek van ,mag en gesag'. Vonk spreek in sy vertaling net van ,gesag'. Die bedoeling is: afdwingbare gesag.

2. Dit bedien die sakramente nie soos Christus dit in Sy Woord verorden het nie, maar neem daarvan af en voeg daaraan toe volgens haar goeddunke (Frans: ,comme il luy plaist', dus: soos dit haar behaag). Ons merk op dat hierdie formulering aansluit by Openb. 22:1, 19, waar die huidige Afrikaanse vertaling spreek van: ,wegneem' en ,byvoeg'.

Die Franse teks het in art. 7 dieselfde werkwoorde as hier: adiouster en diminuer, terwyl daar Openb. 22:18, 19 direk word aangehaal.

Dit is noodsaaklik dat waar die belydenis Bybeltaal spreek, die vertaling dit moet laat blyk, ter wille van konkordansie tussen Belydenis en Bybelvertaling. Die nuwe Afrikaanse Bybelvertaling neig om in fraseologie heeltemal weg te breek van die Belydenisse (waaronder ook die Heid. Kategismus). In 'n tyd van ontmitologisering kan 'n mens so iets verwag.

3. Die eerste punt onderstreep die eiemagtige houding: geen onderwerping aan die juk van Christus nie. By die tweede punt is daar gespreek van 'n afdoen en toedoen ten aansien van die Woord van God. Ten derde word geaksentueer dat die valse kerk meer op mense steun as op Christus (teks van 1561): „sy staet ende gron- 
det haer meer op de menschen, dan op Christus". Latere tekste spreek net van ,fondeert' of ,grondt'. Dit gaan oor die fondament. Die Afrikaanse ,steun" is te swak. Jy kan op jouself staan, maar 'n steun gebruik. Dit gaan hier egter om die absolute basis, die petra van Matt. 16 (Christus in 1 Petr. 2). Die Bybeltaal moet in die vertaling uitkom!

Die houding lei na vervolging van ,protestante' wat teen gebreke soos hebsug en ido(lo) latrie optree.

Ons kan by avaritia dink aan die proteste van Wiclif teen die besit van die kerk (vgl. reeds by Dante). Idolatrië is vorme van beeldediens, die Roomse praktyke met beelde en heiliges.

\section{Die Slot:}

Hierdie twee kerke kan maklik onderken en van mekaar onderskei word. Hierdie vertaling sluit die beste by die Franse teks aan: „pour distinguer l'une d'avec l'autre".

Aan die einde van die gedeelte bevat die bestraffing van die gebreke wat in Openb. 17 aangehaal word. Ook hierin word 'n middeleeuse motief oorgeneem. Vergelyk weer Hfst. 18 van die Skotse Belydenis: ,, The notes . . . quhairby Immaculate spousee of Christ is knawin frome that horrible harlot, the Kirk malignant". Die nadruklike verwysing na Openb. 17 in verskillende uitgawes van die Belydenis moet by die interpretasie van die Belydenis in ag geneem word. 